\title{
Coup Risk, Coup-Proofing Strategy and Leader Survival
}

\begin{abstract}
Under what conditions do political leaders take strategies that allow them to reduce militaries' capabilities to successfully organize a coup? There is a broad consensus among previous studies that political leaders who face a high risk of coup will employ "coup-proofing" strategies. A closer look at their theory and empirical analyses, however, suggests that the presumed relationship between coup risk and coup-proofing should be reexamined. Drawing on insights from formal studies on authoritarian power-sharing, this article proposes that political leaders are less likely to undertake coup-proofing efforts as the coup risk they face increases because militaries can deter leaders from weakening them by threatening a coup. The statistical models in this article estimate a latent coup risk by properly aggregating multiple indicators that capture militaries' willingness and ability to organize a coup. The empirical results strongly support the proposition: Coup-proofing efforts taken by leaders decrease in coup risk.
\end{abstract}




\section{Introduction}

Though a political leader faces multiple threats from both within and outside the political system, the threat of a coup replacement by the military or other elites is considered to be the most crucial for a leader's survival, especially in authoritarian and newly democratized countries. An overwhelming majority of the leaders in these countries lose power as a result of a coup d'etat rather than popular uprisings or civil wars (Galetovic and Sanhueza, 2000). Moreover, the consequence of coup replacement is severe. Unconstitutional removals by coups often result in the exile, imprisonment, or death of the former leader Goemans, 2008). Therefore, developing a strategy to prevent the military and other elites from attempting a coup is a critical task for a leader whose priority is to remain in power.

Existing studies point out that there are so-called "coup-proofing" strategies that a political leader can rely on to diminish the miliary's capability to successfully coordinate the replacement of the leader by a coup (e.g Quinlivan, 1999). These strategies include, for example, establishment of paramilitary organizations that have a different command structure from the regular armed forces, frequent rotation of commanders, and division of the military into many rival branches. When do political leaders undertake these coup-proofing efforts to reduce militaries' capabilities to successfully stage a coup? A large number of scholars have argued or implicitly assumed that political leaders who face a high risk of coup tend to undertake these coup-proofing strategies. As the likelihood that the military and other elites attempt coup d'etat increases, the leader undertakes a greater level of coup-proofing efforts (e.g Biddle and Zirkle, 1996; Quinlivan, 1999; Belkin and Schofer, 2003; Roessler, 2011).

At first glance, the previous studies' conclusion that coup risk has a positive impact on coup-proofing efforts sounds almost obvious. A closer look at their theoretical logic and empirical analyses, however, casts doubt on the presumed relationship between coup risk and coup-proofing. Theoretically, these studies do not take into account the possibility that political leaders' attempts to weaken militaries would prompt them to stage a coup. Empirically, in measuring a coup risk variable, the literature has relied on an ad hoc assumption about how to aggregate multiple coup-related indicators into the measure of coup risk.

Drawing on insights from formal studies on power struggles between a political leader 
and the ruling elite developed in the comparative authoritarian literature (Svolik, 2009, Sudduth, 2014), this article reexamines the relationships between coup risks and coup-proofing efforts by highlighting when militaries can deter the leader from diminishing their coupmaking capabilities by threatening to stage a coup. Contrary to the conventional wisdom, theoretical logics derived from the aforementioned formal studies lead to the proposition that leaders' coup-proofing efforts decrease in coup risk. Political leaders are less likely to take actions that would reduce militaries' coup-making capabilities when they already face a high risk of coup because such actions are most likely to spark coup reactions.

This proposition is tested using a Bayesian analysis. In assessing the relationship between coup risk and coup-proofing, the existing literature uses the composite measure of coup risk that aggregates multiple coup-related indicators (Belkin and Schofer, 2003, 2005). Their aggregation procedure, however, seems to be arbitrary and lacks a formal justification. Unlike these studies, the empirical approach in this article estimates the posterior distribution of latent coup risk by deriving a proper rule as to how to aggregate multiple indicators of militaries' willingness and ability into coup risk measure. The results strongly support the proposition: Coup risk has reducing effects on coup-proofing efforts.

The article proceeds as follows. In the next section, I define the term of coup-proofing strategies and argue that decreasing militaries' capabilities to successfully organize a coup is the key to coup-proofing the regime. The third section overviews the existing studies and details why their claim should be reexamined. The fourth section provides theoretical frameworks. The fifth section provides the empirical results. I conclude with the implications of this article.

\section{Coup-Proofing Strategies}

In this article, I will use the term "coup-proofing” efforts to indicate political leaders' efforts or actions that will reduce militaries' abilities to successfully organize a coup. Coupproofing strategies create structural obstacles for military officers to successfully coordinate against political leaders (Belkin and Schofer, 2003, Powell, 2012). These strategies, for ex- 
ample, include counterbalancing by dividing the military into multiple rival forces, creation of parallel militaries that counterweight the regular armed forces, frequent rotation of command positions and purging of rival military officers (Quinlivan, 1999; Biddle and Zirkle, 1996). As a consequence of repeated coup-proofing efforts taken by political leaders, militaries will eventually find themselves too weak to coordinate to challenge political leaders and thus political leaders are considered to become less vulnerable to the threat of coup d'etat.

Though the coup-proofing literature typically focuses on strategies that will diminish militaries' coordination capabilities (e.g Belkin and Schofer, 2003: Sudduth, 2016), some also focus on leaders' attempts to decrease militaries' willingness to launch a coup by providing them with an increased amount of material, financial and political resources (Huntington. 1991). Spoiling, however, is considered to increase militaries' capabilities to successfully organize a coup and the future coup risk (Feaver, 1999). As militaries with larger material and political resources are better equipped for taking strategic locations and staging a coup, providing militaries with increased resources will increase their capabilities to successfully conduct a coup (Powell, 2012; Acemoglu et al., 2010). Some research confirmed this argument by empirically showing that militaries with higher military expenditures have a higher probability of successful coups (Wang, 1998). Moreover, spoiling could increase the future coup risk as leaders find it difficult to credibly commit not to reduce militaries' benefits in the future. When militaries suspect that leaders would not maintain military benefits, they would preempt such downsizing by resorting to coups (Acemoglu et al. 2010). Thus once political leaders empower militaries with increased resources, they will face a higher probability of coup attempts from these stronger militaries. Spoiling will not coup-proof the regimes. For this reason, this article uses the term "coup-proofing" strategies to indicate only those strategies that reduce militaries' capabilities to successfully overthrow leaders via coup.$^{1}$

\footnotetext{
${ }^{1}$ In the Appendix, I explore in great detail the relationships between coup risk and spoiling.
} 


\section{Coup Risk and Coup-Proofing Efforts}

Under what conditions do political leaders enact coup-proofing strategies? There is a broad consensus in existing studies that political leaders who face high risk of coup d'etat tend to intervene in the militaries to coup-proof the regime (e.g Biddle and Zirkle, 1996: Quinlivan, 1999; Belkin and Schofer, 2003; Pilster and Bohmelt, 2012; Roessler, 2011). As the likelihood that militaries resort to coup d'etat increases, political leaders are more likely to adopt strategies that allow them to diminish the militaries' capabilities to organize coups. For example, Belkin and Schofer (2005, pg. 144) argue that "when the risk of a coup d'etat is high, leaders almost always divide their armed forces into multiple organizations that check and balance each other" and that "high coup risk usually is sufficient to cause leaders to" take these coup-proofing efforts. Pilster and Bohmelt (2012) expect that autocracies are more likely to adopt coup-proofing strategies mainly because autocratic leaders are more vulnerable to coup d'etat.

However, while the existing theoretical logic is intuitive, it overlooks the possibility that political leaders' coup-proofing efforts might prompt the militaries to resort to a coup immediately. The civil-military relations literature has long argued that political intervention in the military's internal affairs or autonomy strongly motivates military officers to attempt a coup (Thompson, 1973, Finer, 1988). Leaders' actions such as dividing the military into multiple forces or creating paramilitary forces that counter-balance the regular army will hurt militaries' corporate interests and thus prompt coup reactions. Furthermore, if political leaders' actions will reduce the militaries' capabilities to organize a coup in the future, it is rational for the militaries to launch a coup and replace the leaders immediately before they lose their coup-making capabilities. Removing political leaders via coup is the ultimate punishment that allows militaries to make the leaders accountable and commit to continuously benefit them (e.g Geddes, 1999). Once leaders have reduced militaries' capabilities to the extent that the militaries are too weak to credibly threaten to stage a coup, the militaries will lose influence over the political leaders' actions (Weeks, 2012). It is, therefore, crucial for militaries to stop leaders' coup-proofing actions by removing the leaders.

Indeed there are many examples where political leaders' acts to weaken the militaries 
prompt immediate coup reactions. For example, in 1999 the Prime Minister of Pakistan Nawaz Sharif dismissed a powerful army chief Gen. Pervaiz Musharraf, while Musharraf was on a visit to Sri Lanka. The military high command, however, refused to follow the orders of newly appointed Ziauddin Butt, and just hours later, the army troops surrounded the Prime Minister's home and replaced Sharif by a bloodless coup. Sharif's action to dismiss Musharraf triggered a coup reaction from the officers who were not satisfied with Sharif's performance. Another example is the 1965 Algerian coup. Colonel Boumedinne, the army chief of staff, conducted a coup when it became clear that President Ben Bella intended to oppose the expansion of the regular army and expand the political rights and size of the people's militia as a counterpoise to the regular army (Zartman, 1970). In Niger, President Diori steadily undermined the army's position during the early 1970s. In addition to putting the army to work on non-military tasks, Diori offended the military officers by gradually replacing the army with a militia organized within his single-party regime. Diori's actions to weaken the army's position hurt the officers' corporate interest and eventually led to the 1974 coup which ousted Diori (Higgott and Fuglestad, 1975, pg. 393-95). Considering militaries' reactions in these examples, one might wonder why a political leader wants to risk causing a coup by making coup-proofing efforts when he already faces a high risk of coup.

\section{A Theory of Coup-Proofing}

Dividing the military into multiple forces or creating paramilitary forces is considered to have a reductive effect on militaries' future coup-making capabilities. Precisely because of this coup-proofing effect, militaries have incentives to overthrow the leader who has moved against them before they lose their abilities to do so. Thus to fully explain when a political leader can undermine the militaries' capabilities, a valid theory needs to take into account (i) how militaries, as strategic actors, would respond to a leader's actions to diminish their capabilities and (ii) how the leader makes decisions on coup-proofing actions given the possibility that his actions might prompt coup reactions. To build a framework for understanding coup-proofing, I will draw on the formal work on power struggles between a leader 
and the ruling elite developed in comparative authoritarian literature (Svolik, 2009; Sudduth, 2014, Boix and Svolik, 2013). Though these studies do not frame their work in terms of "coup-proofing," the dynamics formalized in these studies well capture the key features of a strategic environment that leads to coup-proofing actions. In the following, I will first lay out the strategic settings and theoretical logics formalized by these studies and illuminate how we can understand the fundamental strategic problems facing a leader and militaries in the context of coup-proofing.

The central problem confronting a leader and the ruling elite in the aforementioned studies is that, on one hand, the leader tries to increase the share of his power at the expense of the ruling elite, while the ruling elite wants to deter such opportunistic behaviors by threatening to stage a coup. More precisely, a leader first decides whether or how much to take such opportunistic actions that would shift the balance of power in favor of the leader. The ruling elite then decides whether to launch a coup to oust the leader. The leader's opportunistic actions would become effective in reducing the elite's relative power if the elite decides not to stage a coup in response to the leader's opportunism. Crucially, the balance of power between the leader and the ruling elite in turn defines the likely outcome of coup such that an increase in the leader's share of power relative to the power of the ruling elite decreases the likelihood that an attempted coup would succeed. In other words, a leader's opportunistic actions will have an effect of diminishing the elite's capabilities to successfully organize a coup (i.e. coup-proofing effect). More fundamentally, the balance of power between the leader and the ruling elite determines the relative share of the benefits or resources the leader and the ruling elite would enjoy as it determines their bargaining power. A decrease in the likelihood of a successful coup resulting from an increase in the leader's relative power will increase the amount of the benefits that the leader can exclusively enjoy, while it will reduce the share of the benefits for the ruling elite. It is, therefore, crucial for the elite to stop the leader from diminishing their power by threatening to launch a coup and keep their status quo share of the benefits, while the leader always has incentives to increase his share of the benefits (Svolik, 2009).

The leader, however, would also prefer to avoid sparking coup reactions. As a coup 
outcome is costly, leaders hesitate to engage in opportunistic behaviors when they expect that the likelihood that elites would stage a coup in response is sufficiently high. On the other hand, when they anticipate that the elite will not stage a coup even if they take opportunistic actions, the leaders will move against the elite to shift the power balance in their favor. Therefore, leaders' decisions on whether or how much to shift the distribution of power in their favor ultimately depend on the ability of the ruling elite to credibly threaten to stage a coup should he move against the elite. The higher the likelihood that the elite stages a coup in response to leaders' opportunism, the less likely that a leader chooses to engage in opportunistic behaviors.

Building on these insights, I posit that political leaders will engage in a lower level of coup-proofing efforts as the coup risk they face increases. How likely militaries and other elites are to stage a coup (i.e. coup risk) is a function of (i) how likely a coup attempt is to succeed and (ii) the amount of grievances that military officers and other elites have toward the incumbent leaders (Powell, 2012). Because a failed coup is costly, militaries would hesitate to launch a coup when they expect that a coup is most likely to fail, while they are increasingly likely to launch a coup when they expect a higher chance of succeeding. Dissatisfaction with the leader in the status quo also leaves potential plotters more favorably disposed toward coup activity because the consequences of inaction are less favorable. Thus, an increase in militaries' dissatisfaction with a leader and/or their capabilities to stage a successful coup will increase their abilities to deter the leader's opportunism and consequently reduce the probability with which the leader will weaken the militaries' coup-making capabilities. In high coup risk circumstances where military officers and other elites are already unsatisfied with the political leaders' performance and/or the likelihood that an attempted coup succeeds is high, the leaders' attempts to reduce militaries' capabilities are more likely to prompt the militaries to launch a coup. Political leaders' efforts to coup-proof only provide more grievances and discontent to the already-dissatisfied militaries and, thus, a larger number of officers are willing to participate in the plot against the leader. Knowing that the likelihood that militaries will launch a coup in response is high, the leader facing a high coup risk would prefer to avoid offending the militaries. 
On the other hand, political leaders' actions to weaken militaries are less likely to cause coups when leaders face a lower coup risk. As militaries expect a low chance of successful coup, they are most likely to hesitate to stage a coup. In addition, a low coup risk environment reflects the fact that many officers and citizens are largely happy with leaders' policies and performance. Thus, those officers who are sensitive to and concerned about political leaders' attempts to weaken militaries might find it very difficult to collect a sufficient number of other officers to join them in challenging the leaders. As a consequence, political leaders are able to undertake a greater level of coup-proofing efforts without fear of coup responses.

Political leaders who currently enjoy low risk of coups are motivated to weaken the militaries so that they can maximize the share of the benefits by minimizing militaries' bargaining power. Furthermore, they need to take advantage of a currently low risk of coup to prepare for the future coup risk (Sudduth, 2014). Factors found to affect the likelihood of coups are often time-variant. For example, a good economy increases elites' and citizens' satisfactions with the incumbent leader, boosts the legitimacy of the regime, and thus reduces plotters' dispositions toward coups. The chance of successful coup is also low in this case because a successful coup requires most of the population to at least implicitly support and obey the coup plotters' commands (Welch, 1970, Luttwak, 1968; Galetovic and Sanhueza, 2000). The leaders thus can weaken militaries' coup-making capabilities by, for example, excluding powerful rival officers or increasing the size of loyal forces without prompting coups. Economic performance as well as other factors that can have an impact on how citizens and the military feel about a leader, however, vary over time. Many developing countries in particular suffer from large economic fluctuations. A currently popular leader who enjoys a good economy might lose the support of the public and militaries in the future due to an economic downturn. Recognizing this, political leaders have incentives to intervene in militaries to reduce their coordination capabilities to prepare for the future risk.

Relatedly, individuals and security organizations that were once considered loyal to a political leader often later loom as threats to the leader's political survival. To secure his 
power, a political leader often appoints his friends, relatives and cronies to key positions, and also creates security organizations that carry out purges of his enemies. Though these hand-picked individuals and organizations are expected to remain loyal to and uncritical of the leader (Bratton and van de Walle, 1994), they will often find that their interests diverge from the leader's and thus later become threats to his survival. Recognizing this possibility, the leader needs to remove these hand-picked individuals or security organizations before they become real threats (Haber, 2006). Research also points out that the military's capabilities to coordinate in organizing a coup tend to increase over time if leaders take no action (Farcau, 1994). Thus, to prevent officers from building up their own support bases and loyalty among soldiers and troops over time, leaders such as Iraq's Hussein and Libya's Gaddafi repeatedly rotated their commanders until the end of their rule when their militaries had already been weakened enough Quinlivan, 1999). In sum, leaders who currently enjoy a low risk of coup have good reason to suspect that they might face higher risk of coup in the future. They thus want to diminish the military's coordination capabilities whenever the risk of coup d'etat is low enough that they do not have to fear sparking a counter-coup. The discussion above leads to the following hypothesis:

\section{Hypothesis 1: Coup-proofing efforts taken by political leaders decrease in coup risk.}

While the above discussion highlights that leaders who currently face low coup risk would benefit from intervening in militaries and reducing their coordination capabilities, this benefit might not exceed the costs that coup-proofing would have on countries' military effectiveness. Coup-proofing strategies are considered to lower countries' military effectiveness in international war by deteriorating soldiers' leadership and coordination ability (Reiter and Stam, 2002). Do the benefits of addressing future coup risk and maximizing the share of benefits outweigh the cost of lowering military effectiveness in low coup risk cases? Theoretically we can think of two conflicting scenarios. First, lowering countries' military effectiveness might not be too costly for leaders in low coup risk environments be- 
cause losing an international war does not lead to their removal from power in such cases (Bueno de Mesquita et al., 2003; Weeks, 2008). Specifically, when leaders lack strong elites who are willing and able to punish the leaders via coup, the leaders can expect few domestic consequences for military defeat or for starting fights unwisely (Weeks, 2008, 2012). As leaders won't be punished even in cases of military defeats as long as they keep the militaries' coup-making capabilities low, leaders would increasingly coup-proof when counter-coups are unlikely to occur. This reasoning thus supports Hypothesis 1.

Alternatively, the costs of reducing military effectiveness might outweigh the benefits of coup-proofing when leaders do not face immediate threat of coups. Even when a reliable threat of internal punishment via coups is absent, foreign adversaries can punish leaders of losing countries by executing, imprisoning, exiling them, or imposing new regimes. Having competent militaries is important in deterring foreign and domestic opponents from challenging the regime. Thus improving militaries' fighting capabilities on the battlefield might be more essential for leaders if the likelihood that militaries launch a coup is currently low. This argument expects nonmonotonic relationships between coup risk and coup-proofing since leaders who face high and low risk of coups have a smaller size of coup-proofing efforts than leaders who face a moderate level of coup risk. This is because the benefits of coup-proofing would not exceed the potential costs of lowering military effectiveness when leaders face low coup risks, while the risk of prompting preemptive coups is too high in high risk coup environment. This leads to an inverted U-shaped relationship between coup risk and coup-proofing captured by Hypothesis 2 .

Hypothesis 2: Coup-proofing efforts taken by political leaders would be greatest in moderate levels of coup risk.

\section{Data and Model}

The data is in time-series cross sectional format and the unit of analysis is the country-year. The data includes 200 countries for the period 1968-2003. The dependent variable is the size 
of the coup-proofing efforts taken by political leaders. To capture political leaders' efforts to coup-proof the regime, I use a country's counterbalancing level and the size of paramilitary organizations that counterweight the regular armed forces.$^{2}$ First, counterbalancing is a leader's effort to reduce coup risk by dividing the military and pitting rival armed organizations against one another. Counterbalancing involves "the creation of additional military branches that prevent any one part of the military from controlling too many resources, for example, creating several distinct armies" (Belkin and Schofer, 2003, pg.613) and is considered to be the central element of coup-proofing tactics (Pilster and Bohmelt, 2012). To capture leaders' counterbalancing efforts, Belkin and Schofer (2003, 2005) propose a twodimensional measure that incorporates both the number of military and paramilitary organizations and the relative size of the paramilitary to the regular military.

Their operationalization, however, was recently criticized for incorporating all military and paramilitary organizations, including navy and air force units whose weapon systems are "only of limited suitability in the tactical activities entailed by the conduct or prevention of a coup" (Pilster and Bohmelt, 2012, pg.360). Pilster and Bohmelt (2012) instead suggest that coup-proofing measure should focus only on "ground-based forces" that are most relevant to the act of conducting or preventing a coup. I, therefore, created Belkin and Schofer's counterbalancing measure based only on ground-based forces. Specifically, I first collected the data of military and paramilitary forces from the Military Balance published yearly by the International Institute for Strategic Studies for the period of 1968-2003. This gives us a data set that covers a longer time period compared to those used in previous studies of coup-proofing. I then identified all ground-combat compatible military and paramilitary organizations following Pilster and Bohmelt 2011, 2012) $\mathrm{H}^{3} \mathrm{I}$ then recalculate both the number of military and paramilitary organizations and the relative size of the paramilitary, compute z-scores for each dimension, and then sum these scores into the final Counterbalancing variable (Belkin and Schofer, 2005, pg.155-156). A higher value of Counterbalancing

\footnotetext{
${ }^{2}$ Another plausible coup-proofing measure found in the literature is the data on ethnic exclusion created by Roessler 2011). In the Appendix, I tested the arguments using the ethnic exclusion data and their results are very similar to the results using Paramilitary and Counterbalancing variables.

${ }^{3}$ The author thanks Tobias Bohmelt for his detailed instruction on how to identify ground-based forces using the Military Balance statistics.
} 
indicates that a country engages in a higher counterbalancing effort in that year.

Second, the Paramilitary variable captures the size of paramilitary organizations relative to the size of the regular army. Paramilitary organizations that have a different command structure from the regular armed forces are considered to counterweight the regular armed forces and prevent them from attempting a coup (Quinlivan, 1999; Powell, 2012). In line with the literature, the relative strength of paramilitary forces is calculated as the proportion of the size of the paramilitary organization to the total size of the regular army (i.e. non-paramilitary) and the paramilitary ( $\left.\frac{\text { paramilitary }}{\text { paramilitary }+ \text { army }}\right)$ Belkin and Schofer, 2005. pg.156). I use the logit transformation of this as the dependent variable $!^{4}$

\section{Measuring Coup Risk}

My key independent variable is coup risk. Following the literature, I define coup risk as the likelihood of a coup attempt (e.g Belkin and Schofer, 2003, Casper and Tyson, 2014). The likelihood of a coup is considered to increase as militaries' dissatisfaction with the incumbent leader increases, and as their ability to organize a successful coup increases (e.g Powell, 2014, Bell and Sudduth, 2015). That is, coup risk is a positive function of militaries' willingness and ability to organize a coup $5^{5}$ Operationalization of the coup risk concept, therefore, requires us to properly aggregate various indicators of plotters' willingness and capability into the coup risk measure.

Previous studies that assess the effect of coup risk on coup-proofing rely on a composite measure of coup risk which combines several coup-related indicators. Specifically, Belkin and Schofer (2003) aggregate three coup-related indicators (civil-society strength, political legitimacy and recent coups) into the coup risk measure by computing z-scores for each indicator and then adding these z-scores of three indicators together Belkin and Schofer, 2003, pg. 608). Their measure of coup risk has recently been used, for example, by Powell (2014) who examines the impact of coup risk on diversionary war behaviors. The procedure they used to combine multiple indicators into the coup risk measure, however,

\footnotetext{
${ }^{4}$ Note that $\frac{\text { paramilitary }}{\text { paramilitary }+ \text { army }}$ ranges from 0 to 1 and its actual distribution is not restricted to the middle range. Thus we need to use its logit transformation as the dependent variable in a linear model.

${ }^{5}$ What I call plotter willingness has also been called plotter disposition or motives elsewhere in the literature.
} 
seems to be arbitrary and lacks a formal justification. For instance, they compute z-scores for each coup-related indicator to ensure that their three indicators contribute equally to the final coup risk index (Belkin and Schofer 2003, pg. 608). But why should we believe that all three items - civil-society strength, political legitimacy and recent coups - tap the coup risk equally well? It is perfectly reasonable to expect that one indicator contributes more than others to the coup risk, or the level of contribution is different among multiple indicators. They do not provide a formal justification with regard to why one should put specific weight on specific items when one calculates a coup risk score. It is not clear whether and to what extent their aggregation rule is supported by the data.

Rather than combining various indicators in an ad hoc manner, I use a statistical model to derive a rule for properly aggregating the willingness and capability indicators to produce a coup risk measure. In a Bayesian statistical model below, the probability that a coup attempt will occur for each country-year $(q)$ is modeled as functions of several indicators that capture militaries' willingness and capability. The model also incorporates the idea that coup risk is an unobservable latent variable and that the observable data on coup occurrence are manifestations of the latent coup risk quantity (Treier and Jackman, 2008). The model then estimates a latent coup risk, $q$, for each country-year by using information available from the observed coup attempts and informing us of the proper aggregation rule regarding how much each indicator should contribute to the coup risk measure.

\section{Measurement Model}

To make these ideas more rigorous, consider the following model.

$$
\begin{array}{r}
y_{i t} \sim \operatorname{Bernoulli}\left(q_{i t}\right) \\
\log i t\left(q_{i t}\right)=d z_{i t}
\end{array}
$$

Let $i=1, \ldots, n$ index countries and $t=1, \ldots, m$ index years. $y_{i t}$ is an observed coup event variable for each country-year. This is a binary variable which takes 1 if a country experiences at least one coup attempt in that year and 0 otherwise. The model assumes that the binary coup variable has a bernoulli distribution with a latent coup risk $q_{i t}$. That is, I 
assume that we observe a coup attempt with the probability $q_{i t}$ for each country-year (i.e. $\left.\operatorname{Pr}\left(y_{i t}=1\right)=q_{i t}\right)$. The binary coup variable comes from Powell and Thyne (2011) and it is defined as "attempts by the military or other elites within the state apparatus to unseat the sitting head of government using unconstitutional means (p.252)."

I then modeled the logit of a latent coup risk, $\log i t\left(q_{i t}\right)$, as a linear function of several willingness and capability indicators $\left(z_{i t}\right)$. Specifically, $z_{i t}$ is a vector of country-year characteristics that impact militaries' willingness and capability to organize a coup and thus are plausible sources of variation in the probability of coups. Estimated parameters $d$ will tell us how much each indicator will contribute to the coup risk measure and how we should aggregate these indicators into the measure of coup risk. $z_{i t}$ includes the following variables: Log(GDP/capita), Democracy, Military Regime and Years after the last Coup $:^{6}$

Economic performance is considered to impact potential plotters' willingness and ability to organize a coup. A poor economy makes militaries and other elites less satisfied with the incumbent leader and more favorably disposed toward coup attempts (Collier and Hoeffler, 2005). Plotters are inclined to punish leaders for failed economic policies to hold them accountable (Aksoy et al. 2015). Economic performance also affects plotters' abilities to succeed a coup because poor economic performance can increase the public discontent with the incumbent and their willingness to condone or support a coup attempt. The public's perception is crucial for coups to succeed because tactically-successful coups can be overturned by widespread disapproval among the general public (e.g Galetovic and Sanhueza, 2000). Coup risk thus increases as a state's wealth or economic performance declines (e.g Londregan and Poole, 1990). The Log(GDP/capita) captures a country's general level of economic performance and is obtained from Gleditsch (2002).

Regime type is another indicator to capture coup plotters' abilities and willingness. Citizens in stable democratic societies want to protect their electoral systems and will not support extra-constitutional measures such as coups. Given a lower chance of successful coups, potential plotters are less likely to attempt a coup in democratic societies (Lindberg

\begin{tabular}{|l|}
\hline \hline${ }^{6}$ In the Appendix, I have estimated alternative versions of coup risk measure using different willingness \\
\hline and capability variables. The results produced by these alternative coup risk measure are consistent with the \\
results presented below.
\end{tabular}


and Clark, 2008). There is also a consensus in the literature that military regimes have a higher risk of coups than other types of regimes because they lack legitimacy and popular support (Thyne, 2010). They are more susceptible to internal divisions (Geddes, 1999). The Democracy variable is a binary variable which takes 1 if a country-year is a democracy and 0 otherwise. The Military Regime variable takes a value of 1 if a country-year's regime type is a military dictatorship and 0 otherwise. A base category is a civilian/royal dictatorship. The data is obtained from Cheibub et al. (2010).

Finally, some researchers indicate that countries that have experienced a coup in the recent past are more likely to experience a coup in the present (e.g Belkin and Schofer, 2003). In a country with recent coup experiences, coups have become viewed as an acceptable and even legitimate tactic to challenge the incumbent and militaries are thus more willing to employ such tactics (Roessler, 2011). Potential plotters are also more optimistic about their chances of success when their own coup attempts might be legitimized by a history of coup in the country. To capture "the coup trap" phenomenon (Londregan and Poole, 1990), I include the Years after the last Coup variable, which measures how many years have passed since the last coup attempt in the same country.

\section{Coup-Proofing Model}

I then analyze the effect of latent coup risk $(q)$ estimated by the above measurement model on coup-proofing efforts by using the following models.

$$
\begin{array}{r}
p_{i t} \sim \operatorname{Normal}\left(\mu_{i t}, \sigma^{2}\right) \\
\mu_{i t}=\alpha q_{i t-1}+\beta x_{i t}
\end{array}
$$

$p_{i t}$ is the coup-proofing effort dependent variable and I use both the Paramilitary and Counterbalancing variables. In the linear model for $\mu_{i t}$, I include the lagged latent coup risk variable $q_{i t-1}$ and other sources of variation in the dependent variable $\left(x_{i t}\right) . \alpha$ is a coefficient on latent coup risk and shows the impact of a previous year's coup risk on a political leader's coup-proofing efforts. Hypothesis 1 expects that $\alpha$ should be negative.

To examine Hypothesis 2 which expects an inverted U-shaped relationship between 
coup risk and coup-proofing efforts, I include a quadratic term for coup risk, $q_{i t-1}^{2}$ in the model.

$$
\mu_{i t}=\alpha q_{i t-1}+\gamma q_{i t-1}^{2}+\beta x_{i t}
$$

Hypothesis 2 expects that $\alpha$ should be positive and $\gamma$ should be negative. This is because it expects that the marginal impact of coup risk on coup-proofing efforts $\left(\frac{\text { CCoupProofing }}{\text { dCoupRisk }}=\right.$ $\alpha+2 \gamma \times$ CoupRisk ) is positive when coup risk is small and then becomes negative when coup risk is high.

$x_{i t}$ is a vector of country-year characteristics that are plausible sources of variation in the coup-proofing dependent variable. $\beta$ is a vector of parameters that tap country-year characteristics in $x_{i t}$ to the coup-proofing dependent variable. Specifically, $x_{i t}$ includes the variables Interstate War, Civil War, Democracy and Lag of DV. The Interstate War variable is a binary variable and takes 1 if a country engaged in an interstate war in the previous year and 0 otherwise. The variable is taken from version 4.0 of the War Data Collection compiled by the Correlates of War Project (Sarkees and Wayman, 2010). The Civil War variable is a dichotomous variable indicating whether a country engaged in a civil war in the previous year and is obtained from Fearon and Laitin (2003). These war variables capture and test competing claims provided by the literature. On one hand, war (either international or civil wars) might reduce coup-proofing efforts because leaders are concerned that coup-proofing efforts lower militaries' performances on the battlefield. On the other hand, some leaders might see war as opportunities to intervene in militaries and weaken them (Huntington, 1968; Belkin and Schofer, 2005), because war can justify leaders' actions to send threatening rivals to the war fronts or create elite loyal paramilitaries.

The Democracy variable takes 1 if a country is a democracy in that year and 0 otherwise, and is taken from Cheibub et al. (2010). This variable captures the intuition that a large number of veto players and checks and balances in democratic governments may make it difficult for their leaders to divide the militaries and increase the size of paramilitary organizations loyal to the leaders themselves (Pilster and Bohmelt, 2012). Note, though, that 
Democracy could also influence the coup-proofing level indirectly via coup risk. By controlling Democracy in both the outcome and measurement models, I explicitly model that Democracy might influence coup-proofing effort both directly and indirectly (via coup risk). Finally, I include Lag of DV as coup-proofing efforts in the previous year are likely to influence coup-proofing efforts in a current year. I assign normal prior distributions for the parameters $\alpha, \beta, \gamma$ and $d$. These distributions have a mean of 0 and a variance of 100 . I employ diffuse, independent inverse-Gamma priors on the $\sigma^{2}$ parameters.

\section{Results}

I implemented the Markov chain Monte Carlo (MCMC) algorithm using the Bayesian software WinBUGS. Approximate mixing of three parallel simulated chains was achieved after 3,000 iterations for the measurement model and 1,000 for each outcome (coup-proofing) model. I first discuss the validity of our estimated coup risk measure (i.e. $q_{i t}$ ) by evaluating the aggregation rule derived by the measurement model. The summary of the posterior distributions of the measurement model is shown in Table 1 . Estimated parameters $d$ tell us how one should put specific weights on specific capability and willingness indicators when we construct the measure of coup risk. As I discussed above, various factors such as economic performance and regime types are considered to determine militaries' willingness and ability to organize a coup.

Table 1: Posterior Summaries of Measurement Model

\begin{tabular}{lc}
\hline \hline Dependent Variable: & Coup Attempt \\
\hline \hline \multirow{2}{*}{ Log(GDP/capita) } & -0.404 \\
& {$[-0.584,-0.229]$} \\
Democracy & 0.071 \\
& {$[-0.275,0.430]$} \\
Military & 0.382 \\
& {$[0.083,0.680]$} \\
Years Since Last Coup & -0.078 \\
& {$[-0.097,-0.061]$} \\
Constant & 0.833 \\
& {$[-0.429,2.165]$} \\
\hline $\mathrm{N}$ & 6057 \\
DIC & 1929.6 \\
\hline \hline Note. Table entries are posterior means; $95 \%$ Bayesian credible intervals are shown in square brackets.
\end{tabular}

The results in Table 1 show that estimated coup risk measure is a positive function of 
plotters' willingness and capability captured by various indicators. For example, the posterior means of the coefficients on the $\log ($ GDP/capita $)$ is negative and their $95 \%$ Bayesian credible intervals are below zero. Negative coefficients on the $\log (G D P /$ capita $)$ variables indicate that better economic performance will decrease the probability that a country experiences a coup. This is thus consistent with the idea that poor economic performance increases plotters' dissatisfaction with the incumbent leader and that a good economy reduces plotters' capability as it increases the public's support for the leader. I also find that military regimes are more likely to experience a coup attempt than other types of regimes. The posterior mean of the coefficients on the Military Regimes is positive and its $95 \%$ Bayesian credible interval is above zero. This confirms the idea that military regimes have a higher risk of coups as they are more susceptible to internal divisions (high disposition) and tend to lack the legitimacy and popular support (high ability). Finally, the posterior mean of the coefficients on Years after Coup is negative and the $95 \%$ Bayesian credible interval are below zero, suggesting that the more time that has passed since the last coup attempt, the less likely it is that a country will experience a coup. This is consistent with the previous studies' understanding that coup risk is higher in a country with recent coup experiences because recent coups boost both militaries' willingness and capability to execute a coup.

The results in Table 1 also indicate that the existing approach used by Belkin and Schofer to aggregate coup-related indicators into coup risk is problematic. Although Belkin and Schofer assume that each coup-related indicator equally contributes to the measure of coup risk, the results of my measurement model clearly show that different indicators have different levels of contribution to the coup risk measure. For example, the Military Regime indicator has a larger level of contribution than the Democracy indicator. The posterior means of the coefficients on the Military Regime variable are around 0.38, while the posterior means of the coefficients on the Democracy variable are 0.07. The result itself is not surprising. Nonetheless it implies that the existing measure of coup risk that relies on an ad hoc assumption that each indicator equally contributes to the final coup risk measure is unreliable and that the empirical results based on the existing coup risk measure should be reconsidered. 
I now analyze the impacts of latent coup risk $\left(q_{i t-1}\right)$ on coup-proofing efforts. The summary of the posterior distributions from eight slightly different outcome models are shown in Table 2. Models 1, 2, 3 and 4 use a logit of Paramilitary as the dependent variable while Models 5, 6, 7 and 8 use the Counterbalancing variable as the dependent variable. In Hypotheses 1 and 2, I made two conflicting predictions and decided to let the data adjudicate between them. Hypothesis 1 states that an increase in coup risk will decrease leaders' coup-proofing efforts suggesting that there is a negative linear relationship between coup risk and coup-proofing efforts. Meanwhile, Hypothesis 2 argues that coup-proofing efforts first increase and then decrease in coup risk predicting a nonmonotonic relationship between coup risk and coup-proofing efforts. In Models 1 and 5, I test a linear relationship between coup risk and coup-proofing. The posterior summaries of both Models 1 and 5 provide us with strong evidence for Hypothesis 1. The posterior means of the coefficient on coup risk are negative and their $95 \%$ Bayesian credible intervals are below zero. This indicates that an increase in coup risk in the previous year will decrease a political leader's coup-proofing efforts measured by the relative size of paramilitary organizations and the counterbalancing level.

I then test Hypothesis 2 in Models 2 and 6 that include quadratic terms of Coup Risk. The results of Models 2 and 6 do not support an inverted U-shaped relationship suggested by Hypothesis 2. First, the $95 \%$ Bayesian credible intervals of the coefficient associated with the quadratic term (Coup Risk ${ }^{2}$ ) include zero.7 Thus we do not find evidence that the marginal impact of coup risk on coup-proofing depends on coup risk (i.e. nonlinear relationships). In addition, the coefficients are not in the direction indicated by Hypothesis 2 . Though Hypothesis 2 expects that the coefficient on the linear term Coup Risk is positive and the coefficient associated with the quadratic term Coup Risk ${ }^{2}$ is negative, the results show that the coefficient on Coup Risk is negative and the coefficient on Coup Risk ${ }^{2}$ is negative in Model 2 and positive in Model 6. Furthermore, including the quadratic term for coup risk does not improve the model fits. The Deviance Information Criteria (DIC) of Models 2 and 6 is slightly larger than that of Models 1 and 5. In sum, we do not find support for an inverted

\footnotetext{
${ }^{7}$ I confirmed that the $90 \%$ credible intervals for the coefficient on Coup Risk ${ }^{2}$ still include zero, while the 90 $\%$ credible intervals for the coefficient on Coup Risk are below zero.
} 
U-shaped relationship between coup risk and coup-proofing expected by Hypothesis 2 .

Though the results of Models 1 and 5 support Hypothesis 1, one potential concern might be that the estimated negative effect of latent coup risk on coup-proofing might pick up the effect of observed coup attempt on coup-proofing because we use information on observed coups to estimate latent coup risk in the measurement model. The issue here is that observed coup attempt might affect not only my key independent variable -coup riskbut also the coup-proofing dependent variable negatively as, for example, leaders who experiences coups might hesitate to provoke militaries and therefore reduce coup-proofing measures accordingly. To address the potential problem of omitted variable biases, I control Coup Attempt $t_{t-1}$ in Models 3 and 7 in Table 2. The results still hold and the posterior summary of Models 3 and 7 provides us strong evidence consistent with Hypothesis 1 . The posterior means of the coefficient on coup risk are negative and their $95 \%$ Bayesian credible intervals are below zero. On the other hand, the coefficients on Coup Attempt $t_{t-1}$ are not significant. In addition, Models 4 and 8 analyze the impacts of coup risk on coup-proofing efforts by using only the sample of country-year observations that have no coup attempts in the previous year (i.e. Coup Attempt $t_{t-1}$ takes a value of zero). The posterior means of the coefficient on Coup Risk $k_{t-1}$ are negative and their $95 \%$ Bayesian credible intervals are below zero. As Models 4 and 8 only use the observations that do not experience observed coups, the reductive effects of Coup Risk on coup-proofing cannot be explained by variations in observed coups. Variations in latent coup risk do matter for country-years where actual coups do not occur and latent coup risk has negative impacts on leaders' coup-proofing efforts as predicted by Hypothesis 1 . 


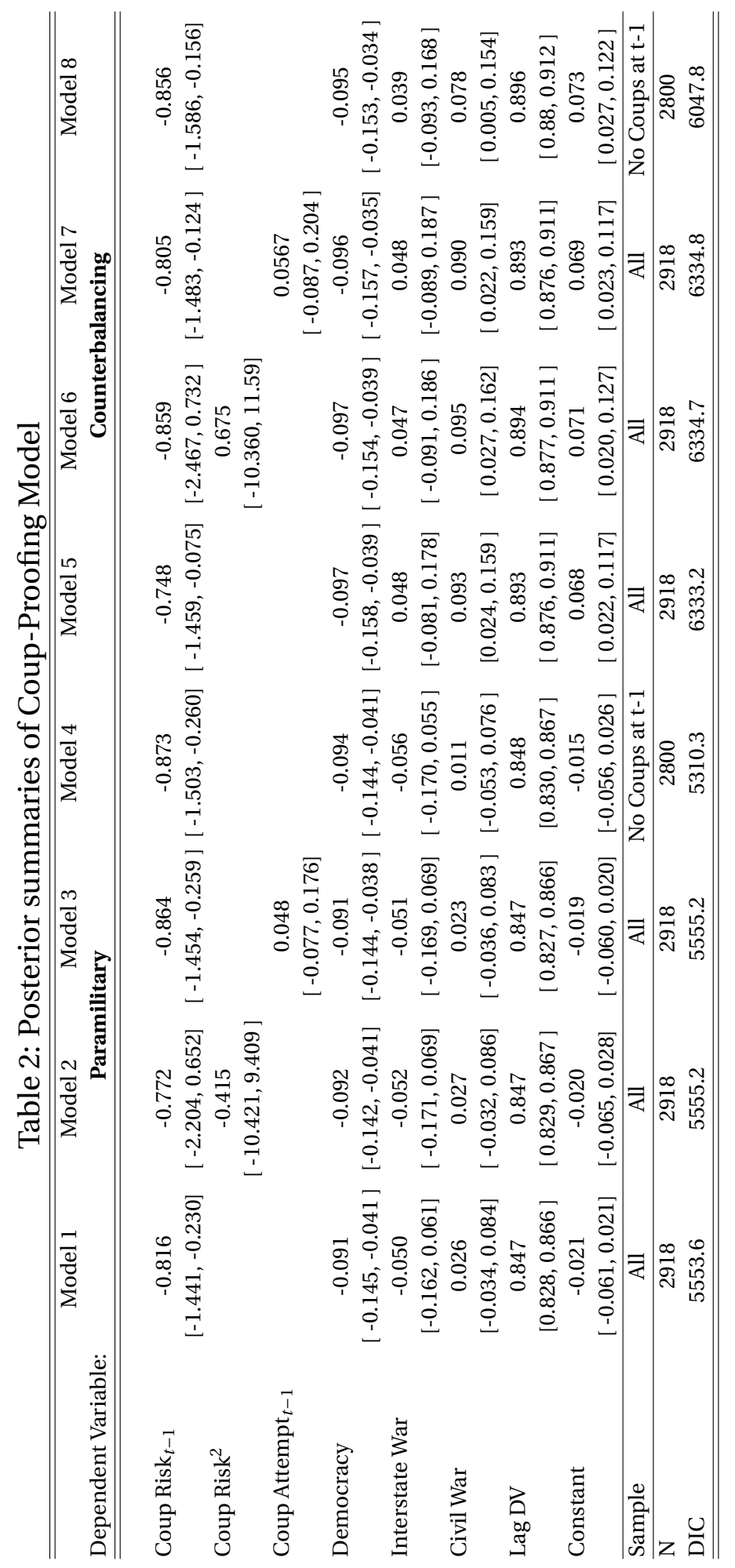


Overall, the results in Table 2 support the argument that an increase in coup risk in the previous year will decrease a political leader's coup-proofing efforts measured by the relative size of paramilitary organizations and the counterbalancing level. To visualize the impact of coup risk on coup-proofing efforts, in Figure 1, I plot how the Paramilitary and Counterbalancing dependent variables change as the latent coup risk changes. On the $\mathrm{x}$ axis, I have a latent coup risk. On the y-axes, I have the predicted value of the Paramilitary and Counterbalancing variables with the $95 \%$ credible interval lines around the predicted lines. The predicted values of the coup-proofing variables are calculated by holding other variables at their medians or means. Figure 1 shows, for example, when coup risk changes from 0 to 0.1 in the previous year, the proportion of the size of paramilitary organization will decrease from 0.37 to 0.35 . Similarly, a counterbalancing score decreases from 0.08 to 0.01 when coup risk increases from 0 to 0.1 .

Figure 1: Effect of Latent Coup Risk on Coup-Proofing Effort

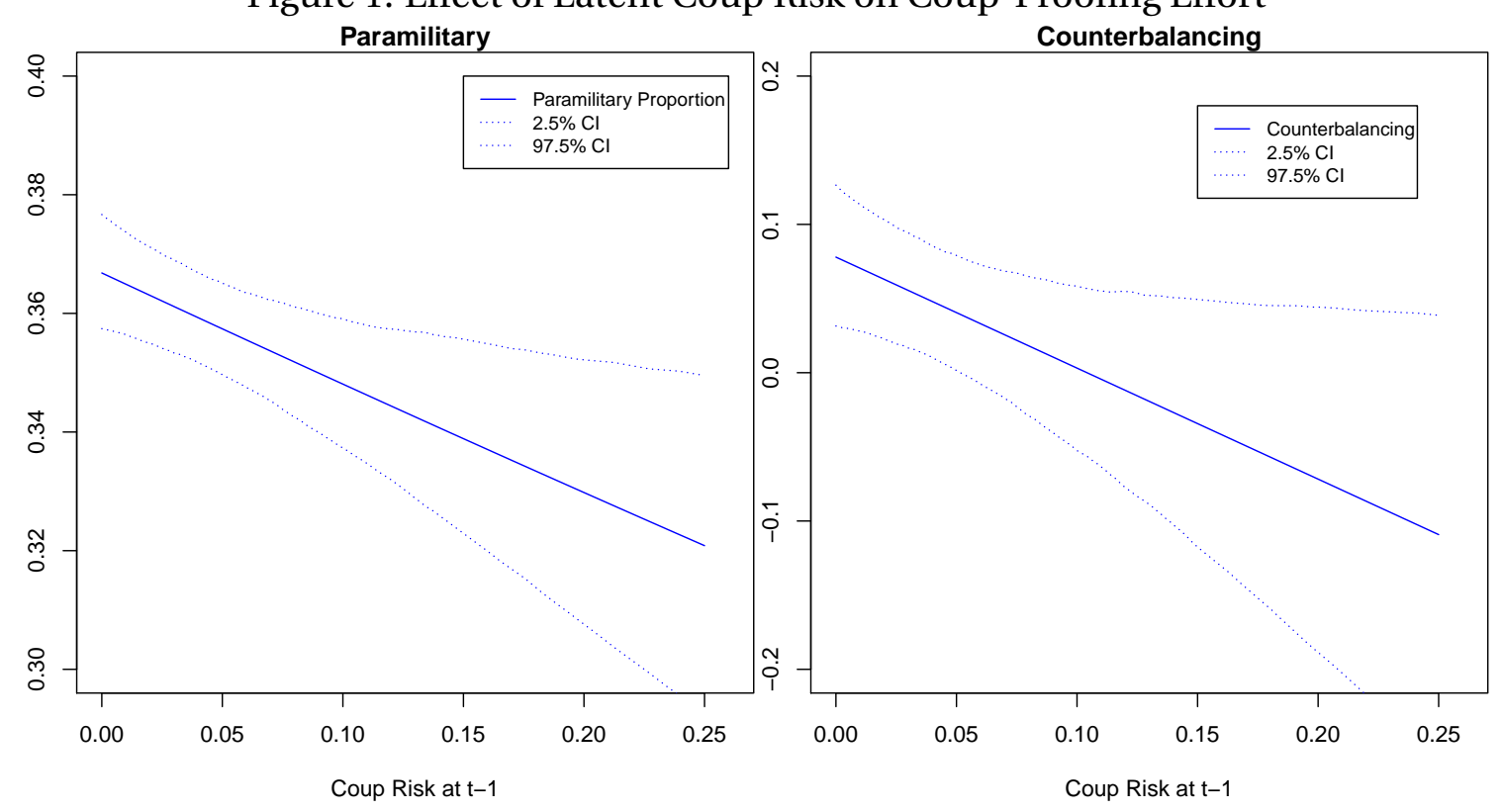

In terms of control variables, the posterior means of the coefficients on the Lag DV variable are positive and their $95 \%$ Bayesian credible intervals are above zero in all eight models, which is consistent with the previous finding (Pilster and Bohmelt, 2012). There is also evidence that civil war increases leader's counterbalancing efforts, which supports a claim that leaders see ongoing war as opportunities to coup-proof by creating and exacerbating rivalries among branches of their forces (Belkin and Schofer, 2005). Negative coeffi- 
cients on Democracy indicate that democracies have a lower level of coup-proofing efforts. Note, though, that the literature argues that democracies are less likely to undertake coupproofing efforts partly because they have lower risk of coup (Pilster and Bohmelt, 2012), the empirical results in the manuscript suggest that this is not exactly the case. The results of the measurement model in Table 1 show that democracy does not have significant effect on coup risk. The negative coefficients on Democracy in the outcome model thus indicate that democracies reduce coup-proofing efforts because of reasons not related to their coup risk such as a larger number of veto players and the system of checks and balances.

\section{Conclusion}

The findings in this article naturally lead to the following question: If political leaders can enact coup-proofing strategies only when coup risk is low, what can political leaders do when they face a high risk of coup? Previous studies have pointed out that political leaders can prevent a coup attempt not only by reducing militaries' capabilities to successfully stage coups, but also by diminishing militaries' grievances toward the incumbent leaders (Powell, 2012). Political leaders facing a high risk of coup can avoid an immediate threat of coup attempts by providing militaries with increased financial and political resources (Huntington, 1991). Yet, political leaders need to be very cautious about the strategy of spoiling militaries with resources. Although spoiling militaries with increased resources might reduce the immediate risk of coup, it increases militaries' capabilities to successfully stage a coup and thus increases the future probability of successful coup (Acemoglu et al., 2010). Expecting a higher chance of a successful coup, stronger militaries with larger resources will be more likely to attempt a coup (Acemoglu et al. 2010, Svolik, 2013). Thus, the strategy of spoiling will eventually increase the coup risk facing political leaders and, therefore, will worsen their situations. The findings in this article also speak to and partly explain the coup trap phenomenon. Since leaders facing high coup risk cannot rely on coup-proofing strategies to protect them from the future coup threats, high coup risk countries find it difficult to escape from the perpetual cycle of coup recurrences. This indeed highlights a difficult situ- 
ation that political leaders with a high risk of coup face. 


\section{References}

Acemoglu, D., Ticchi, D., and Vindigni, A. (2010). Persistence of Civil Wars. Journal of the European Economic Association, 8(2).

Aksoy, D., Carter, D. B., and Wright, J. (2015). Terrorism and the Fate of Dictators. World Politics, 67(3):423-468.

Belkin, A. and Schofer, E. (2003). Toward a Structural Understanding of Coup Risk. Journal of Conflict Resolution, 47(5):594-620.

Belkin, A. and Schofer, E. (2005). Coup Risk, Counterbalancing, and International Conflict. Security Studies, 14(1):140-177.

Bell, C. and Sudduth, J. K. (2015). The Causes and Outcomes of Coup During Civil War. Journal of Conflict Resolution. Forthcoming.

Biddle, S. and Zirkle, R. (1996). Technology, Civil-Military Relations, and Warfare in the Developing World. The Journal of Strategic Studies, 19(2):171-212.

Boix, C. and Svolik, M. (2013). The Foundations of Limited Authoritarian Government: Institutions, Commitment, and Power-Sharing in Dictatorships. Journal of Politics, 75(2):300316.

Bratton, M. and van de Walle, N. (1994). Patrimonial regimes and Political Transitions in Africa. World Politics, 46(4):453-89.

Bueno de Mesquita, B., Smith, A., Siverson, R. M., and Morrow, J. D. (2003). The Logic of Political Survival. MIT Press, Cambridge, MA.

Casper, B. A. and Tyson, S. A. (2014). Popular Protest and Elite Coordination in a Coup d'etat. The Journal of Politics, 76(2):548-564.

Cheibub, J. A., Gandhi, J., and Vreeland, J. R. (2010). Democracy and Dictatorship Revisited. Public Choice, 143(1). 
Collier, P. and Hoeffler, A. (2005). Coup Traps: Why does Africa have so many Coups d'Etat? . Working paper.

Farcau, B. W. (1994). The Coup: Tactics in the Seizure of Power. Praeger, Westport, CT.

Fearon, J. D. and Laitin, D. D. (2003). Ethnicity, Insurgency, and Civil War. American Political Science Review, 97(1):75-90.

Feaver, P. (1999). Civil-Military Relations. Annual Review of Political Science, 2(1):211-241.

Finer, S. (1988). The Man on Horseback: The Role of the Military in Politics. Westview, Boulder, CO.

Galetovic, A. and Sanhueza, R. (2000). Citizens, Autocrats, and Plotters: A Model and New Evidence on Coups D'etat. Economics and Politics, 12(2):183-204.

Geddes, B. (1999). What Do We Know about Democratization after Twenty Years. Annual Review of Political Science, 2:115-44.

Gleditsch, K. (2002). Expanded trade and GDP data. Journal of Conflict Resolution, $46(5): 712-724$.

Goemans, H. (2008). Which Way Out? The Manner and Consequences of Losing Office. Journal of Conflict Resolution, 52(6):771-794.

Haber, S. (2006). Authoritarian Government. In Wittman, D. and Weingast, B. R., editors, The Oxford Handbook of Political Economy. Oxford University Press.

Higgott, R. and Fuglestad, F. (1975). The 1974 Coup d'Etat in Niger: Towards an Explanation. The Journal of Modern African Studies, 13(3):383-398.

Huntington, S. P. (1968). Political Order in Changing Societies. Harvard University Press, Cambridge, MA.

Huntington, S. P. (1991). The Third Wave. University of Oklahoma Press, Norman.

Lindberg, S. I. and Clark, J. F. (2008). Does Democratization Reduce the Risk of Military Interventions in Politics in Africa? Democratization, 15(1):86-105. 
Londregan, J. B. and Poole, K. T. (1990). Poverty, the Coup Trap, and the Seizure of Executive Power. World Politics, 42.

Luttwak, E. (1968). Coup D'Etat: A Practical Handbook. Harvard University Press, Cambridge, MA.

Pilster, U. H. and Bohmelt, T. (2011). CoupÜProofing and Military Effectiveness in Interstate Wars, 1967Ü99. Conflict Management and Peace Science, 28(4):331-350.

Pilster, U. H. and Bohmelt, T. (2012). Do Democracies Engage Less in Coup-Proofing? On the Relationship between Regime Type and Civil-Military Relations. Foreign Policy Analysis, 8(4):355Ü372.

Powell, J. (2012). Determinants of the Attempting and Outcome of Coups d'etat. Journal of Conflict Resolution, 56(6):1017-1040.

Powell, J. (2014). Regime Vulnerability and the Diversionary Threat of Force. Journal of Conflict Resolution.

Powell, J. and Thyne, C. (2011). Global Instances of Coups from 1950-2010: A New Dataset. Journal of Peace Research, 48(3).

Quinlivan, J. T. (1999). Coup-proofing: Its Practice and Consequences in the Middle East. International Security, 24(2):131-165.

Reiter, D. and Stam, A. C. (2002). Democracies at War. Princeton University Press, Princeton and Oxford.

Roessler, P. (2011). The Enemy Within: Personal Rule, Coups, and Civil War in Africa. World Politics, 63(2):300-346.

Sarkees, M. R. and Wayman, F. (2010). Resort to War: 1816 - 2007. CQ Press, Washington, DC.

Sudduth, J. K. (2014). Strategic Logic of Elite Purges in Dictatorships. Annual Meeting of the American Political Science Association, DC. 
Sudduth, J. K. (2016). Coup-Proofing and Civil War. In Thompson, W. R., editor, The Oxford Research Encyclopedia of Politics. Oxford University Press.

Svolik, M. W. (2009). Power Sharing and Leadership Dynamics in Authoritarian Regimes. American Journal of Political Science, 53(2):477-494.

Svolik, M. W. (2013). Contracting on Violence: Authoritarian Repression and Military intervention in Politics. Journal of Conflict Resolution, 57(5):765-794.

Thompson, W. R. (1973). Grievances of Military Coup-Makers. Sage, Beverly Hills, CA.

Thyne, C. L. (2010). Supporter of stability or agent of agitation? The effect of US foreign policy on coups in Latin America, 1960-99. Journal of Peace Research, 47(4):449-461.

Treier, S. and Jackman, S. (2008). Democracy as a Latent Variable. American Journal of Political Science, 52(1):201-217.

Wang, T. (1998). Arms Transfers and Coups d'Etat: A Study on sub-Saharan Africa. Journal of Peace Research, 35(6):659-675.

Weeks, J. L. (2008). Autocratic Audience Costs: Regime Type and Signaling Resolve. International Organization, 62:35-64.

Weeks, J. L. (2012). Strongmen and Straw Men: Authoritarian Regimes and the Initiation of International Conflict. American Political Science Review, 106(2):326-347.

Welch, C. (1970). Soldier and State in Africa. Northwestern University Press, Evanston, IL.

Zartman, I. W. (1970). The Algerian Army in Politics. In Welch, C. E., editor, Soldier and State in Africa. Evanston: Northwestern University Press. 